\title{
ORIGINAL
}

\section{Reflex Discharges of Hypoglossal Nerve Elicited by Palatal Nerve and Glossopharyngeal Nerve Stimulation in Frogs}

\author{
Hiroshi Kajiya \\ Department of Oral Physiology, Fukuoka Dental College \\ (Chief : Prof. Hiroyuki Soeda) \\ 2-15-1 Tamura, Sawara-ku, Fukuoka 814-01, Japan
}

〔Received on September 11, 1996 ; Accepted on March 12, 1997〕

Key words : palatal nerve stimulation/glossopharyngeal nerve stimulation/reflex discharges/tongue movement $/$ frogs

\begin{abstract}
Reflex discharges of the hypoglossal nerve elicited by electrical stimulation of the palatal nerve (PNS) were compared with those of the same nerve elicited by glossopharyngeal nerve stimulation (GNS) in frogs. The results were as follows : 1 . threshold of the stimulation for eliciting discharges was higher in PNS than in GNS, 2. frequency and latency of the PNS-elicited discharges were lower and longer than those of GNS, respectively, 3. the PNS-elicited discharges consisted of one component with short latency, while those of GNS consisted of two components with short and long latencies, respectively, 4. the GNS-elicited discharges were facilitated by conditioning PNS, 5. PNS elicited discharges only in the hyoglossal branch of hypoglossal nerve controlling the tongue as a retractor, while GNS elicited discharges in the hyoglossal branch that functions as a retractor, and in the intrinsic and genioglossal branches as protractors, 6. the PNSand GNS-elicited discharges were similar in characteristics to those elicited by tactile stimulation of the palate and tongue, respectively.

These findings suggest that the sensory input from the palatal nerve polysynaptically elicits retraction of the tongue for transport of bolus from the oral cavity into the pharynx, while that of the glossopharyngeal nerve mono- and/or poly-synaptically elicits retraction and protraction of the tongue for bolus transport and rejection, respectively.
\end{abstract}

抄録：口蓋神経の電気刺激により舌下神経に誘発される反射性放電を舌咽神経刺激による放電と比較した。口 蓋神経刺激による放電は舌咽神経刺激による放電に比較して, 放電を誘発する刺激の䦣值は高く, 放電の頻度は 低く，潜時は長かった。口蓋神経刺激による放電パターンは長い潜時を持つ成分のみで，舌咽神経刺激によるパ ターンは短い潜時と長い潜時を持つ二つの成分であった。口蓋神経に条件刺激を与えた後の舌咽神経刺激による 放電は促進された。口蓋神経刺激による放電は, 舌の引き込み運動を支配する舌下神経の分枝にのみ認められ, 舌咽神経刺激による放電は引き込みと突き出し両運動を支配する分枝に認められた。以上の結果より， 口蓋神経 からの感覚入力は多シナプス性に舌の引き込み運動を誘発し, 舌咽神経からの入力は単シナプス性と多シナプス 性に舌の引き込みと突き出しの両運動を誘発することが示唆された。

\section{Introduction}

The movement of the tongue during mastication and swallowing is controlled by the reflex sensory input from the oral cavity. Electrical stimulation of the glossopharyngeal nerve elicits massive reflex discharges in the hypoglossal nerve innervating the tongue in frogs $^{1 \sim 3)}$. This indicates that the glossopharyngeal nerve controls the reflex movement of the 
tongue for food intake.

Electrical and mechanical stimulation of the palate elicit the reflex movement of the jaw in the rat and cat $^{4 \sim 8)}$. The movement is occasionally accompanied by movements of the tongue ${ }^{5 \sim 7}$. Reflex EMG activity of the extrinsic tongue muscle is elicited by electrical and mechanical stimulation of the palate in the cat ${ }^{9,10}$. These findings suggest that the sensory input from the palate through the palatal nerve is an important factor in reflex jaw and tongue movements. However, little is known about the reflex pathway from the palatal nerve to the hypoglossal nerve in reflex tongue movement.

The purpose of the present study was to determine whether the reflex pathway for tongue movement is mono- or poly-synaptic and how the reflex relates to protraction and retraction of the tongue. Therefore, reflex discharges of the hypoglossal nerve were investigated in the frog. First, the characteristics of the discharges elicited by palatal nerve stimulation (PNS) were compared with those elicited by glossopharyngeal nerve stimulation (GNS) under various experimental conditions. Secondly, the effects of conditioning PNS on the reflex discharges were examined. Thirdly, peripheral innervation of the tongue was determined by recording the discharges in some branches of the hypoglossal nerve controlling tongue retraction and protraction. On the basis of the results, the possible role of the sensory input from the palatal and glossopharyngeal nerves is discussed in relation to the reflex control of tongue movement.

\section{Materials and Methods}

Bullfrogs (Rana catesbeiana) were used throughout the experiment. Frogs were anesthetized with MS-222 (ethyl $\mathrm{m}$-aminobenzoate methansulfonate, $100 \mathrm{mg} / \mathrm{kg}$ intraperitoneally) after slight ether anesthesia and laid on their backs on a board. The frogs were maintained under light anesthesia by additional administrations of one tenth of the first dose to prevent spontaneous movement. The hypoglossal nerve after being dissected from surrounding tissues was cut proximally, and attached to a pair of recording electrodes in a small paraffin bath. The palatal and

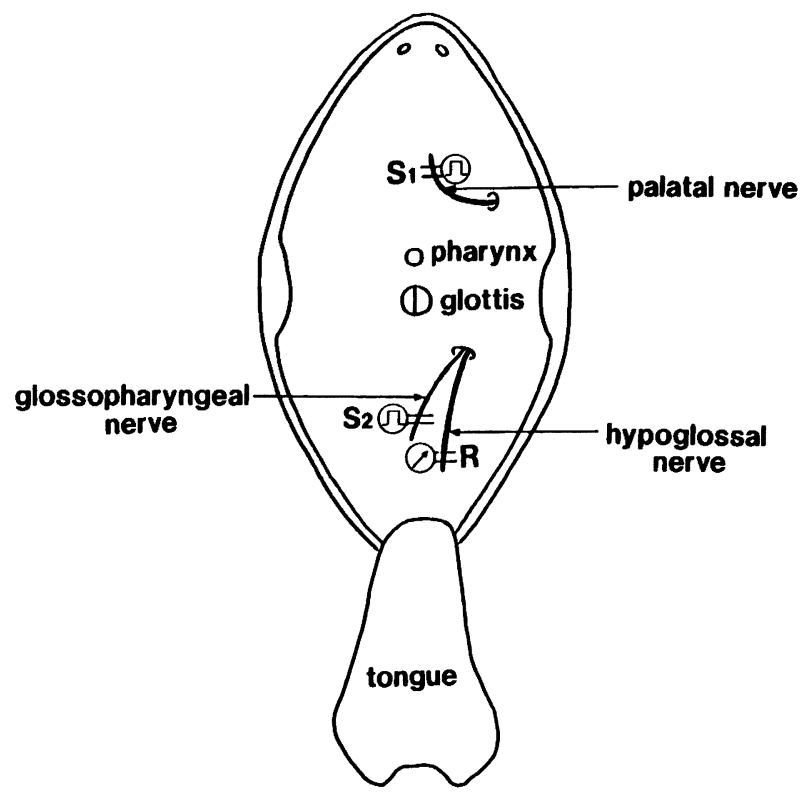

Fig.1 Schematic arrangement of the nerves, the stimulus $\left(S_{1}\right.$ and $\left.S_{2}\right)$ and recording $(R)$ electrodes in the mouth of the frog. The genioglossal, intrinsic, hyoglossal and styloglossal branches of the hypoglossal nerve, and their recording electrodes are omitted to avoid a complication of the figure.

glossopharyngeal nerves were also freed and their distal ends were mounted on the stimulus electrodes. In some experiments, four branches of the hypoglossal nerve (genioglossal, intrinsic, hyoglossal and styloglossal branches) were separated and their discharges were recorded. The arrangement of the stimulus and recording electrodes on the nerve is shown in Figure 1. The length of each nerve between the stimulus or recording electrode and the proximal end emerging from the brain stem was fixed at $13 \mathrm{~mm}$.

For PNS and GNS, rectangular pulses of $0.1 \mathrm{msec}$ duration were used with changes in their number, interval and intensity, and reflex discharges were recorded from the ipsilateral hypoglossal nerve. The discharges were monitored on an oscilloscope (Nihon Kohden, VC-10) and stored on data recorder (TEAC, $\mathrm{R}-61$ ). The number of discharges was counted using a histogram analyzer (Nihon Kohden, DAB-1100). Student's t-test was used to determine statistical significance.

Latency of the reflex discharges was determined by measuring the time between the onsets of the stimulus 
and discharges. However, the latency included time required for conduction of both afferent and efferent nerves of the pathway. Hence, the latency was obtained by subtracting the conduction time of the two nerves from the overall reflex latency. The conduction time was obtained in parallel experiments by measuring the interval between a single pulse and its elicited compound action potential in the nerve of 13 $\mathrm{mm}$.

In the experiments on the effects of conditioning stimulation on the reflex discharges, a conditioning stimulus was applied to the palatal nerve, and then a test stimulus was applied to the glossopharyngeal nerve with successive change in time between the two stimuli. For mechanical stimulation, the tongue and palate were scratched with a glass rod.

\section{Results}

\section{Stimulation for eliciting discharges}

No significant spontaneous discharge was observed in the hypoglossal nerve in the resting state. PNS with a single pulse at intensity of $1.0 \mathrm{~V}$ elicited no reflex discharge in the nerve even though the pulse intensity was increased to $5.0 \mathrm{~V}$. However, two or more train pulses with intensity of $1.0 \mathrm{~V}$ at an interval of $10 \mathrm{msec}$ elicited discharges with a relatively long latency (upper records in Fig. 2). In contrast, GNS with both single and two-train pulses elicited massive discharges. Both discharges were similar in pattern and latency (lower records in Fig. 2).

These results show that the discharges elicited by PNS are closely related to the number of stimulus pulses in contrast to those elicited by GNS. Therefore, the relationship between the pulse number of PNS with change in pulse interval and the discharge number of the hypoglossal nerve was examined. As summarized in Figure 3, the discharges increased and then decreased in number depending on the stimulus pulse number regardless of difference in pulse interval. However, the rates of increasing and decreasing discharges became higher, and the attaining time to a maximum became shorter in reverse proportion to the pulse interval of stimulation. Although the stimulus pulse number and interval were different with each stimulation, the maximum of discharge number with all stimulus conditions almost showed a constant value. From these finidngs, two-train pulses with 10 msec interval were most effective for eliciting discharges.
A

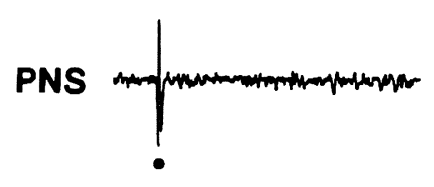

GNS

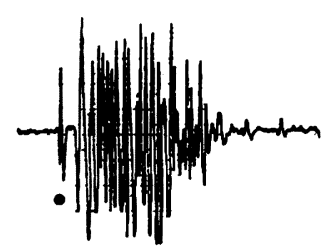

B
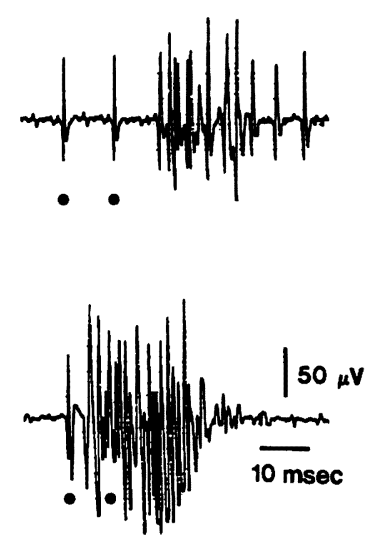

Fig. 2 Reflex discharges of the hypoglossal nerve elicited by PNS and GNS with single pulse (A) and two-train pulses with interval of $10 \mathrm{msec}(B)$ at intensity of $1.0 \mathrm{~V}$. The dot in each record indicates a stimulus artifact. 


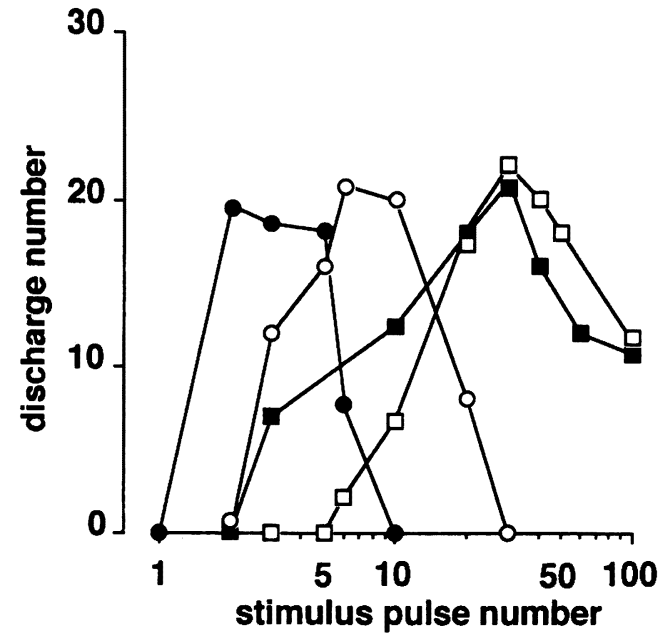

Fig. 3 Relationship between the pulse number of PNS with change in pulse interval and number of discharges in the hypoglossal nerve. The pulse interval is represented by $10(\bigcirc), 20(\bigcirc), 50(\square)$ and $100 \mathrm{msec}(\square)$. Each point in the figure shows mean value obtained from seven frogs, and its SD is omitted to avoid a complication of the figure.
The discharges elicited by GNS with a single and two-train pulses of $1.0 \mathrm{~V}$ were very similar in frequency, amplitude and latency. Therefore, in the following comparison between the discharges elicited by PNS and GNS, single pulse was used for GNS and two -train pulses were used for PNS.

\section{Comparison between discharges elicited by PNS and GNS}

The reflex discharges of the hypoglossal nerve elicited by PNS and GNS at different stimulus intensities were compared (Fig. 4-A). PNS with intensity of $0.3 \mathrm{~V}$ elicited no reflex discharge. Increasing the intensity up to $0.5 \mathrm{~V}$ or more elicited discharges. The discharges increased in frequency and duration, and were saturated depending on the intensity. In contrast, the GNS with intensity of $0.3 \mathrm{~V}$ elicited reflex discharges. They increased in frequency and duration in the same way as those of PNS with increasing the stimulus intensity. However, the discharges elicited by
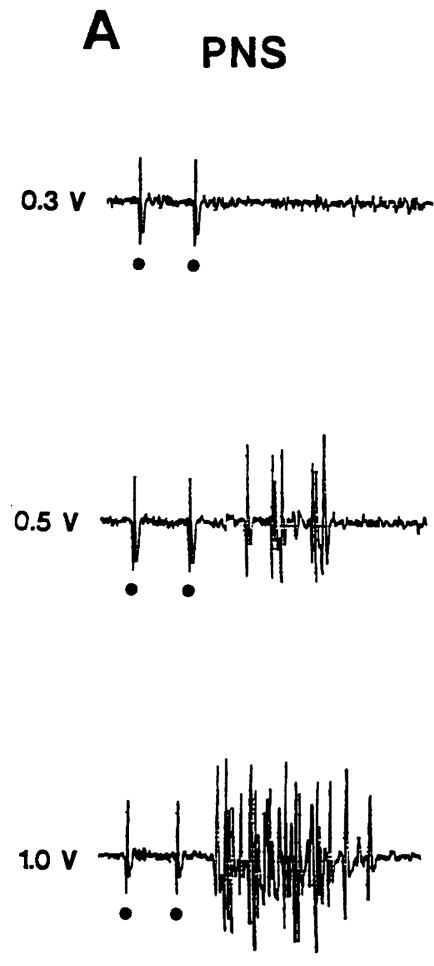
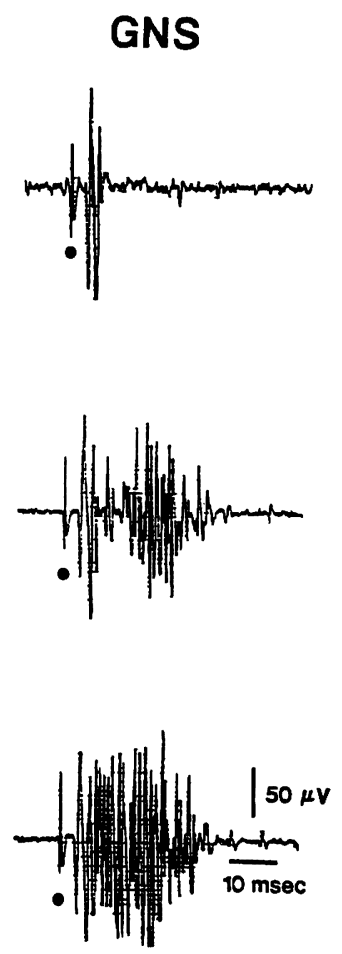
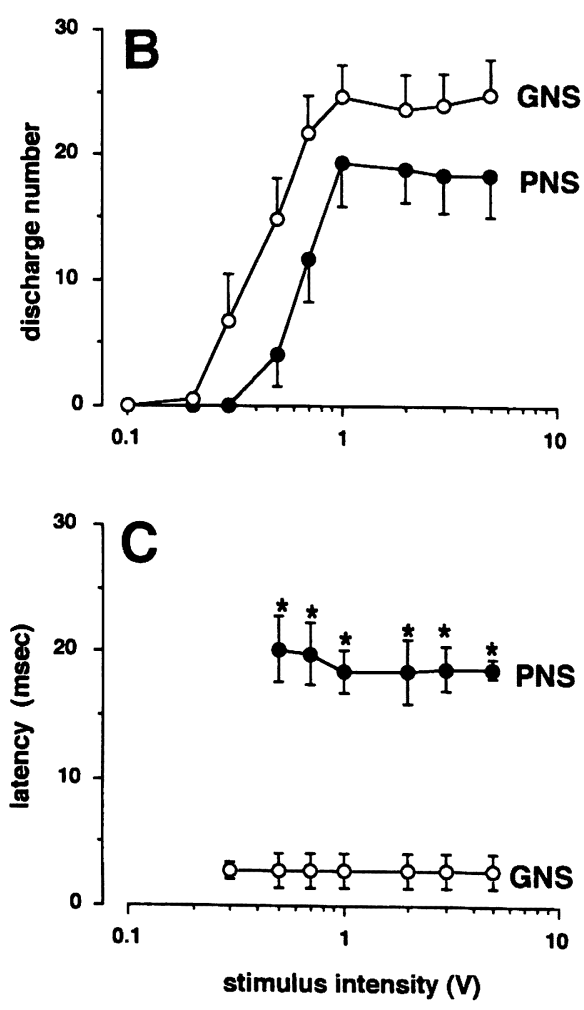

Fig. 4 A : Reflex discharges of the hypoglossal nerve elicited by PNS and GNS with change in stimulus intensity. B : Relationship between the stimulus intensity and discharge number. C : Relationship between the stimulus intensity and discharge latency. The latency was significantly longer in PNS than in GNS $(\mathrm{P}<0.01)$ 
PNS was lower in frequency than that of GNS, as summarized in the relationship between the stimulus intensity and discharge number (Fig. 4-B). The threshold for PNS-elicited discharges was $0.5 \mathrm{~V}$, and the discharge number increased with stimulus intensity up to $1.0 \mathrm{~V}$ where the number reached a plateau. There was a similar relationship with GNS, but the discharge number was higher than PNS over a whole range of stimulus intensity.

The relationship between the stimulus intensity of PNS and GNS, and the latency of discharges is shown in Figure 4-C. The latency was revised by subtraction of conduction time in the peripheral afferent and efferent nerves. The conduction time was $0.76 \pm 0.16$ msec $(n=14)$ in the palatal nerve, $0.74 \pm 0.13 \mathrm{msec}$ $(n=14)$ in the glossopharyngeal nerve and $0.67 \pm 0.10$ msec $(n=10)$ in the hypoglossal nerve (each nerve 13 $\mathrm{mm}$ ). The latency of the discharges elicited by PNS was at its maximum with stimulus intensity of $0.5 \mathrm{~V}$; the latency decreased with increase of stimulus intensity and attained a steady minimum $(18.4 \pm 2.5 \mathrm{msec}$, $\mathrm{n}=12)$ at $1.0 \mathrm{~V}$. In contrast, the much shorter latency of the discharge elicited by GNS was nearly constant $(2.2 \pm 1.3 \mathrm{msec}, \mathrm{n}=12)$ regardless of the change in stimulus intensity. The latency was longer in PNS than in GNS $(\mathrm{P}<0.01)$.

Discharge pattern with change in stimulus intensity

To elucidate the difference in pattern between the reflex discharges of the hypoglossal nerve elicited by PNS and GNS, the discharge number was counted at $2 \mathrm{msec}$ intervals by a histogram analyzer. Figure 5 shows the discharge count sequences of the reflex discharges with change in stimulus intensity, which were the sum data of 30 experiments. The discharges elicited by PNS increased in frequency with increasing stimulus intensity up to $2.0 \mathrm{~V}$ and remained unchanged thereafter, and the pattern consisted of one component with a relatively long latency (18.4 \pm 2.5 $\mathrm{msec}$ ) and constant duration ( $60 \mathrm{msec}$ on average) regardless of change in stimulus intensity.

Conversely, the discharges elicited by GNS at low intensity showed a component with a short latency $(2.2 \pm 1.3 \mathrm{msec})$, which was followed by a subsequent component with a long latency $(12.9 \pm 2.8 \mathrm{msec}) \mathrm{de}$ - pending on the stimulus intensity. Both initial and subsequent components of the discharges were finally incorporated into one component at the intensity of $1.0 \mathrm{~V}$. Therefore, the discharge duration became longer with increasing intensity, and the final duration was $60 \mathrm{msec}$ on average. From both series of the discharge patterns, the maximal intensity of stimulation was estimated as $1.0 \mathrm{~V}$ for PNS and GNS.

\section{Effects of conditioning PNS on reflex discharges}

The data described above clearly indicate that both the palatal and glossopharyngeal nerves synaptically connect to the hypoglossal motoneuron in the brain stem, and suggest that the number of connecting fibers is smaller in the former than in the latter. Therefore, to determine the input of the palatal nerve in relation to that of the glossopharyngeal nerve on the activity of the hypoglossal motoneuron, effects of conditioning PNS on the GNS-elicited discharges of the hypoglossal nerve were examined with changes in interval between PNS and GNS as shown in Figure 6 -A. For conditioning PNS and test GNS, two-train pulses with $10 \mathrm{msec}$ interval and a single pulse at a supramaximal intensity of $2.0 \mathrm{~V}$ were used, respectively. As shown in Figure 6-B, at first, discharges elicited by test GNS without application of conditioning PNS were recorded as the control. Successive application of conditioning PNS and test GNS with interval of $1,000 \mathrm{msec}$ elicited discharges, respectively, but the GNS-elicited discharges remained unchanged in number, duration and pattern compared with those of the control (PNS-elicited discharges not shown). When the interval between conditioning PNS and test GNS (C-T interval) was successively shortened from 1,000 msec, the discharges were increased, and then decreased in frequency and duration depending on the shortness of the interval.

Figure 6 - $\mathrm{C}$ shows the relationship of the $\mathrm{C}-\mathrm{T}$ interval to the number of GNS-elicited discharges. In the figure, the ordinate shows the relative number of discharges compared with that of the control. The conditioning PNS increased the number of discharges at the interval range from 10 to $100 \mathrm{msec}$. The interval to elicit a maximum discharge was $33 \mathrm{msec}$ on average. Thus, the conditioning PNS facilitated GNS- 
PNS
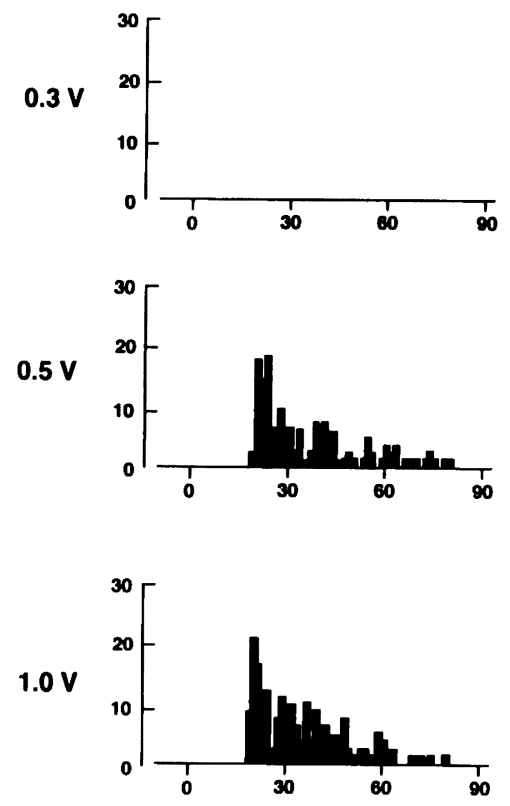
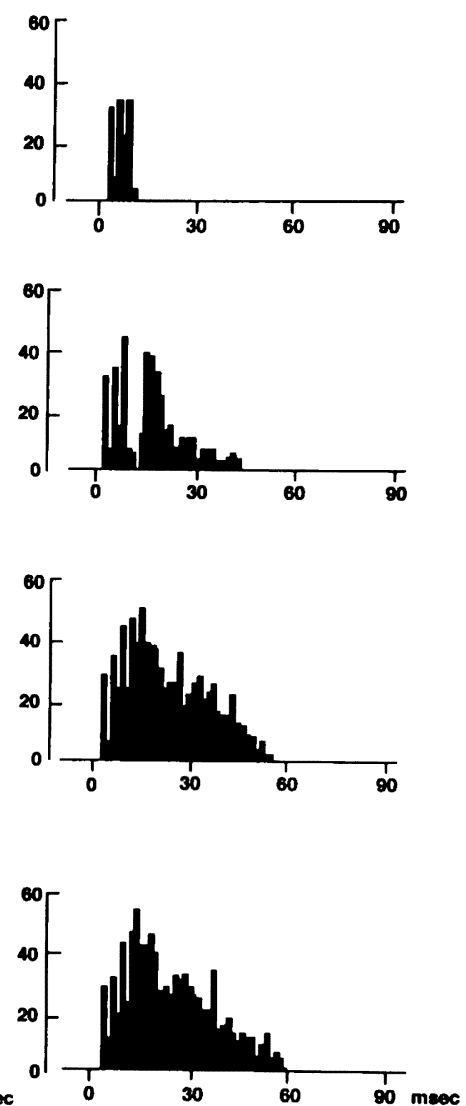

Fig. 5 Discharge count sequences of the reflex discharges in the hypoglossal nerve elicited by PNS and GNS at various stimulus intensities. Each sequence represents the sum of discharge number at $2 \mathrm{msec}$ intervals obtained from 30 experiments.

elicited discharges at the appropriate period of the interval.

\section{Discharges of branches in hypoglossal nerve}

To understand the tongue movement elicited by PNS and GNS, reflex discharges were recorded from the genioglossal, intrinsic, hyoglossal and styloglossal branches of the hypoglossal nerve (Fig. 7). For PNS and GNS, two-train pulses with interval of $10 \mathrm{msec}$ and intensity of $1.0 \mathrm{~V}$, and a single pulse with in intensity of $1.0 \mathrm{~V}$ were used, respectively. PNS elicited discharges only in the hyoglossal branch innervating the tongue as a retractor. In the other three branches, no discharge was elicited when the intensity was increased up to $5.0 \mathrm{~V}$. In contrast, GNS elicited dis- charges in three branches: the hyoglossal branch innervating the tongue as a retractor, and the genioglossal and the intrinsic branches that function as protractors. Neither PNS nor GNS elicited discharge in the styloglossal branch.

\section{Discharges elicited by mechanical stimulation}

When the palate and tongue of the frog were stimulated mechanically with movement of a glass rod, reflex discharges were recorded from the hypoglossal nerve (Fig. 8). The discharges elicited by palatal stimulation were low in frequency and long in latency compared with those of tongue stimulation. These characteristics were similar to those elicited by electrical PNS and GNS. The latency of discharges 
A

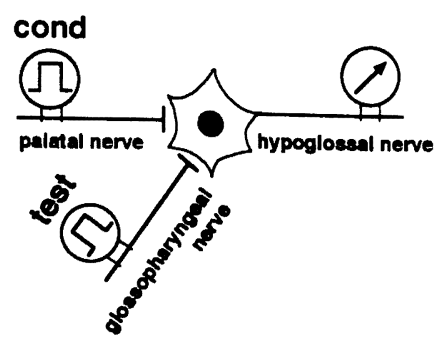

B

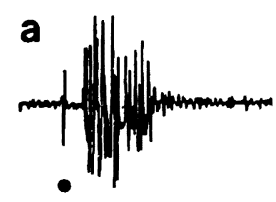

b

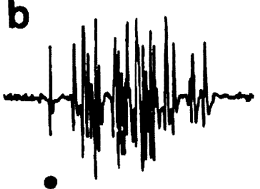

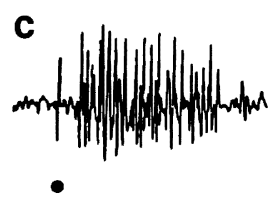

d

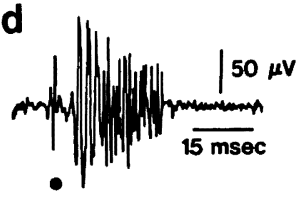

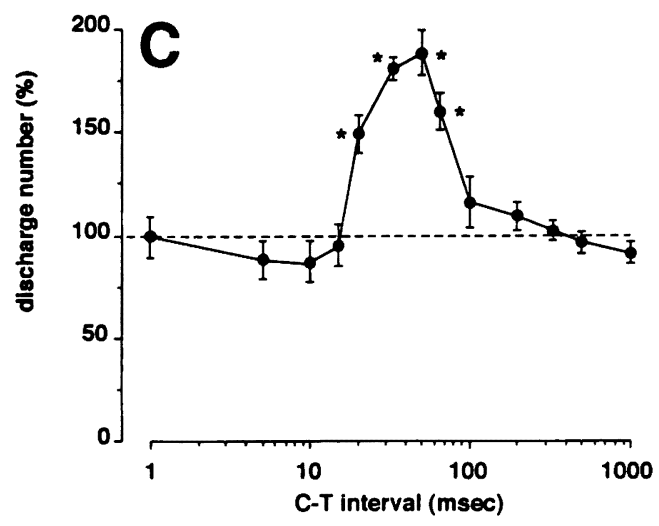

Fig. 6 Effects of conditioning stimulation on the reflex discharges. A : Arrangement of the electrodes placed on the nerve. B : Record a shows the reflex discharges of the hypoglossal nerve elicited by test GNS without application of conditioning PNS as control. Records b to $d$ show the discharges elicited by test GNS 100, 33 and $10 \mathrm{msec}$ after application of conditioning PNS, respectively. Each record does not show the discharges elicited by the conditioning PNS.

$\mathrm{C}$ : Relationship of the interval between conditioning PNS and test GNS (C-T interval) to the relative number of discharges in contrast to that of control $(100 \%)$. The data were obtained from seven frogs, and the symbol of $\star$ shows significant increase in discharge number compared with that of control $(\mathrm{P}<0.05)$.

\section{Protraction}

genioglossal branch

intrinsic branch

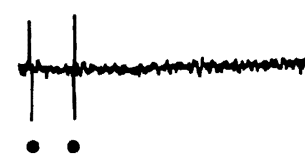

PNS

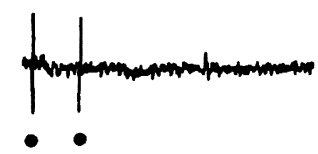

\section{Retraction}

hyoglossal branch

styloglossal branch
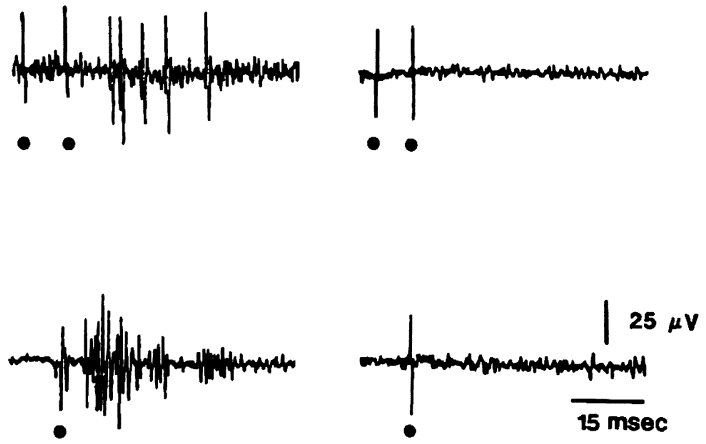

Fig. 7 Reflex discharges elicited by PNS and GNS of $1.0 \mathrm{~V}$ in four branches of the hypoglossal nerve, which innervate the tongue for its protraction and retraction. 

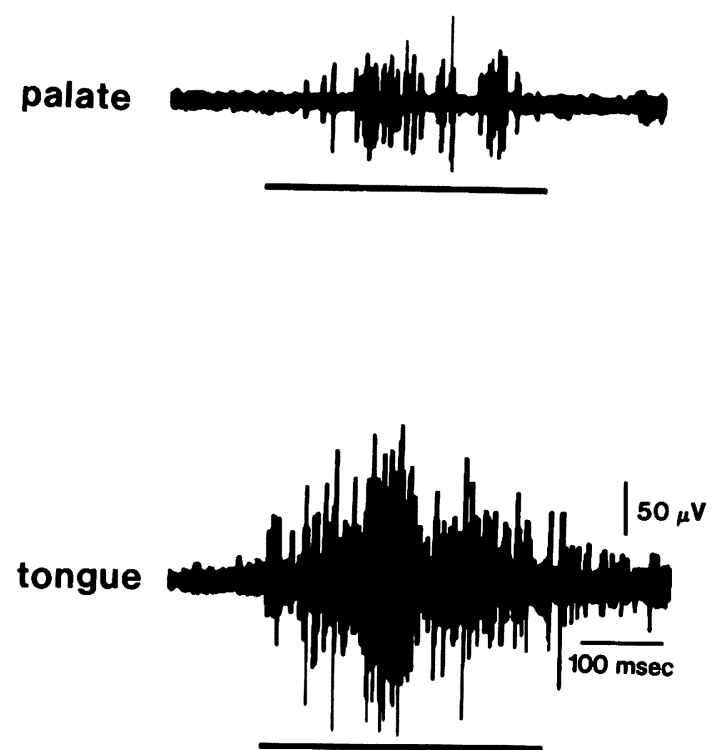

Fig. 8 Reflex discharges of the hypoglossal nerve elicited by tactile stimulation of the palate and tongue with movement of a glass rod. The horizontal bar beneath each record indicates the stimulus duration.

was estimated at $30 \mathrm{msec}$ for the palatal stimulation and $10 \mathrm{msec}$ for the tongue stimulation, respectively. These latencies of mechanical stimulation were much longer than those of electrical stimulation as mentioned above.

\section{Discussion}

It is known that the GNS elicits reflex discharges in the hypoglossal nerve innervating the tongue in frogs ${ }^{1 \sim 3)}$. The present study has confirmed this, and has shown that PNS also elicited reflex discharges in the hypoglossal nerve. However, the discharges elicited by PNS are in many respects different from those of GNS. These findings suggest that the tongue is regulated by the sensory input from the palatal nerve in parallel with that from the glossopharyngeal nerve, although the regulation by the two nerve inputs differs.

The reflex discharges of the hypoglossal nerve elicited by electrical PNS were similar to those elicited by mechanical stimulation of the palate, but the latency of discharges was much shorter in the electri- cal stimulation than in the mechanical stimulation. Results similar to that of PNS and palatal stimulation were observed by electrical GNS and mechanical stimulation of the tongue. These findings were in agreement with the work of Hellstrand in experiments using cats ${ }^{10}$. The latency of EMG activity in the extrinsic tongue muscle elicited by mechanical stimulation of the palate in $30-35 \mathrm{msec}$, which is much longer than by electrical stimulation of the palate (about $10 \mathrm{msec}$ ). The retardation of the discharge latency elicited by mechanical stimulation may be due to converting the mechanical stimulus into the discharges of the nerve.

The conduction times of the palatal and glossopharyngeal nerves at $13 \mathrm{~mm}$ were $0.76 \pm 0.16$ and $0.74 \pm 0.13$ msec, respectively. From the conduction time, the conduction velocity of the palatal nerve calculated $(17.1 \mathrm{~m} / \mathrm{sec})$ was almost the same as that of the glossopharyngeal nerve $(17.6 \mathrm{~m} / \mathrm{sec})$, and the value of the glossopharyngeal nerve was in approximate agreement with that of mechanosensory fibers in the frog tongue ${ }^{3,11}$. Although the conduction velocities of the two nerves were identical, the pattern of the reflex discharges elicited by PNS in the hypoglossal nerve consisted of one component with long latency (18.4 \pm $2.5 \mathrm{msec}$ ), while that of GNS was consisted of two components with short and long latencies, respectively $(2.2 \pm 1.3$ and $12.9 \pm 2.8 \mathrm{msec})$. These findings suggest that the palatal nerve contains mechanosensory fibers, but that its synaptic connection to the hypoglossal nerve differs from that of the glossopharyngeal nerve fibers. According to Lowe et al. ${ }^{9}$, EMG activity in the extrinsic muscle of the tongue elicited by electrical stimulation of the palate had a long latency in cats $^{8)}$. Araki and Otani ${ }^{12)}$ reported that the synaptic latency of the monosynaptic reflex in the frog spinal cord is $1.3-2.7 \mathrm{msec}$. Therefore, one component of the discharges with $18.4 \mathrm{msec}$ in latency elicited by PNS indicates that the palatal nerve fiber is polysynaptically connected to the hypoglossal motoneuron in frogs.

In contract GNS elicited discharges consisting of two components with short and long latencies, respectively. The discharges are consistent in pattern with the glossopharyngeal-hypoglossal nerve reflex as has been reported for the frog and toad ${ }^{1,2,13,14)}$. Matsu- 
shima et $a l .^{13)}$ reported that the glossopharyngeal nerve connects with the hypoglossal motoneuron through mono- and poly-synaptic pathways in the toad, and the latencies of mono- and poly-synaptic pathways are 1-4 and 3-11 msec, respectively. Therefore, the two components of the discharges in the hypoglossal nerve elicited by GNS may be ascribed to mono- and poly-synaptic pathways of the reflex, respectively.

The tongue is innervated by branches of the hypoglossal nerve for complicated movement. In the frog, the hypoglossal nerve is classified into two branch types, one innervates protractor muscles and the other innervates retractor muscles ${ }^{15}$. The genioglossal and intrinsic branches belong to the former, and the hyoglossal and styloglossal branches belong to the latter. PNS elicited discharges only in the hyoglossal branch, while GNS elicited discharges in the hyoglossal, intrinsic and genioglossal branches. These findings indicate that the sensory input from the palatal nerve mainly controls the retraction of the tongue, while that from the glossopharyngeal nerve controls both protraction and retraction.

The reflex discharges of the hypoglossal nerve elicited by the GNS were facilitated by the conditioning stimulation of the palatal nerve. The discharges increased in number and duration in a range from 10 to $100 \mathrm{msec}$ of intervals between conditioning and test stimuli. Facilitation similar to the present findings has been observed in EPSP of the hypoglossal motoneuron by application of the conditioning stimulation of glossopharyngeal nerve in the frog ${ }^{13)}$ and cat ${ }^{16,17)}$. It is suggested, therefore, that the conditioning stimulation temporally and spatially facilitates the activity of hypoglossal motoneurons, resulting in the enhancement of discharge number. In addition, the tongue retraction elicited by sensory input from the glossopharyngeal nerve may be enhanced by a preceding input from the palatal nerves.

There have been many studies concerning EPSP and IPSP of the hypoglossal motoneuron in a variety of animals ${ }^{18 \sim 21)}$. However, little literature is available concerning those of PNS. Morimoto et $a l .^{18)}$ and Lowe $^{20)}$ demonstrated that stimulation of the cat lingual nerve produces EPSP, or EPSP followed by IPSP in the retractor hypoglossal motoneuron, and IPSP in the protractor hypoglossal motoneuron. According to electromyography, the latency and prolonged duration of the activity in the extrinsic muscles of the tongue elicited by the lingual stimulation are similar to those of PNS in cats $^{10)}$. These findings suggest that PNS evokes EPSP in the retractor motoneuron and IPSP in the protractor motoneuron. In the present experiment, PNS elicited the reflex discharges only in the hyglossal branch innervating retractor motoneurons. Therefore, the discharges may be caused by EPSP in the retractor hypoglossal motoneuron. In contrast, GNS elicited discharges in the retractive and protractive branches. The discharges correspond to GNS-elicited EPSP in the retractor and protractor motoneurons of various animals ${ }^{13,19,20)}$. Therefore, the GNS-elicited discharges of the retractive and protractive branches may be caused by EPSP in each motoneuron.

There is a regional difference in stimulus effect of the jaw-opening reflex elicited by electric stimulation of the oral mucosa in the cat and rat $^{5 \sim 7}$. In the cat, mechanical stimulation of the posterior palate elicits a jaw-closing reflex, while stimulation of the anterior palate elicits jaw-opening reflex ${ }^{22}$. According to Tomomune and Takata ${ }^{21}$, electrical stimulation of the superior laryngeal nerve with train pulses elicits EPSP in the retractor hypoglossal motoneurons and IPSP or EPSP followed by IPSP in protractor hypoglossal motoneurons in the cat. These findings suggest that the retractor motoneuron is activated and the protractor motoneuron is inhibited during the buccopharyngeal stage of swallowing. Therefore, the PNSelicited discharges obtained in the present study may elicit retraction of the tongue together with jaw-closing for the transport of bolus, from the oral cavity to the pharynx in the swallowing process in the same manner as those of the superior laryngeal nerve.

In contrast, the GNS-elicited discharges differ in function from PNS-elicited discharges, because the discharges cause the tongue to retract and protract. The discharges may ascribe to different function of transport and rejection in food intake. Thus, the sensory inputs from both the palatal and glossopharyngeal nerves may alternatively enhance bolus transport because the conditioning stimulation of the pala- 
tal nerve facilitated the GNS-elicited discharges of the hypoglossal nerve.

\section{References}

1) Kumai, T. : Reflex response of the hypoglossal nerve induced by chemical stimulation of the tongue and electrical stimulation of the glossopharyngeal nerve in the frog. Jpn. J. Physiol. 31 : 625 637, 1981.

2) Nakachi, T. and Ishiko, N. : Gustatory signal processing in the glossopharyngeo-hypoglossal reflex arc of the frog. Jpn. J. Physiol. 36:189 $\sim 208,1986$.

3) Hirakawa, T., Honda, E., Toyoshima, K., Tomo, S. and Nakahara, S. : Glossopharyngeal-hypog. lossal nerve reflex of the frog in metamorphosis. Archs oral Biol. $38: 123 \sim 129,1993$.

4) Yemm, R. : Reflex jaw opening following electrical stimulation of oral mucosus membrane in man. Archs oral Biol. $17: 23 \sim 33,1972$.

5) Thexton, A. J. : Oral reflexes elicited by mechanical stimulation of palatal mucosa in the cat. Archs oral Biol. 18 : 971 980, 1973.

6) Weijs-Boot, J. and van Willigen, J. D. : Jaw reflexs elicited by electrical stimulation of the hard palate of the rat. Archs oral Biol. $23: 259$ $\sim 264,1978$.

7) van Willigen, J.D. and Weijs-Boot, J. : Phasic and rhythmic responses of the oral musculature to mechanical stimulation of the rat palate. Archs oral Biol. $29: 7 \sim 11,1984$.

8) Takata, M., Tomioka, S. and Tomomune, N. : Synaptic potentials produced in jaw-closer and jaw-opener motoneurons by palatal stimulation. Exp. Brain Res. 90 : 233 240, 1992.

9) Lowe, A. A., Gurza S. and Sessle, B. J. : Excitatory and inhibitory influences on tongue muscles activity in cat and monkey. Brain Res. 113 : 417 422, 1976.

10) Hellstrand, E. : Reflex control of cat extrinsic and intrinsic tongue muscles exerted by intraoral receptors. Acta Physiol. Scand. 115 : 245 256, 1982.

11) Hanamori, T. and Ishiko, N. : Conduction veloc- ity of the IXth nerve fibers innervating taste organs in the rostral and caudal tongue region in bullfrog. Chemical Senses $6: 175 \sim 187,1981$.

12) Araki, T. and Otani, T. : Response of single motoneurons to direct stimulation in toads' spinal cord. J. Neurophysiol. $18:$ 472 485, 1995.

13) Matsushima, T., Satou, M. and Ueda, K. : Glossopharyngeal and tectal influences on tongue-muscle motoneurons in the Japanese toad. Brain Res. 365: 198 203, 1986.

14) Hirakawa, T. : A study of averaged waves of reflex discharges in the frog hypoglossal nerve elicited by electrical stimulation of glossopharyngeal afferent. J. Kyushu dent Soc. 32 : 119 131, 1989.

15) Satou, M., Matsushima, T., Takeuchi, H. and Ueda, K. : Tongue-muscle-controlling motoneurons in the Japanese toad : topography, morphology and neuronal pathways from the 'snappingevoking area' in the optic tectum. J. Comp. Physiol. 157 : 717 737, 1985.

16) Hunter, I. W. and Porter, R. : Glossopharyngeal influences on hypoglossal motoneurons in cats. Brain Res. 74 : 161 166, 1974.

17) Lowe, A. A. : The neural regulation of tongue movement. Progr. Neurobiol. $15: 295 \sim 344,1981$.

18) Morimoto, T., Takata, M. and Kawamura, Y. : Effects of lingual nerve stimulation on hypoglossal motoneurons. Exp. Neurol. 37 : 188 198, 1968.

19) Duggan, A. W., Lodge, D. and Biscoe, T. J. : The inhibition of hypoglossal motoneurons by impulses in glossopharyngeal nerve of the rat. Exp. Brain Res. $17: 261 \sim 270,1973$.

20) Lowe, A. A. : Excitatory and inhibitory inputs to hypoglossal motoneurons and adjacent reticular formation neurons in cats. Exp. Neurol. 62:30 $\sim 47,1978$.

21) Tomomune, N. and Takata, $M:$ Excitatory and inhibitory postsynapic potentials in cat hypoglossal motoneurons during swallowing. Exp. Brain Res. $71: 262 \sim 272,1988$.

22) Takata, M., Tomioka, S. and Nakajio, N. : Excitation and inhibition of trigeminal motoneurons by palatal stimulation. Exp. Brain Res. 87: 497 $\sim 504,1991$. 